\title{
Engendering England: The Restructuring of Allegiance in the Writings of Richard Morison and John Bale
}

JACQUELINE A. VANHOUTTE

Summary: This paper examines the way in which old systems of allegiance are interrogated, and replaced by an emergent nationalism in two writers closely associated with the Cromwell government: Richard Morison and John Bale. In their attempt to contruct nationhood in sixteenth-century England, both Morison and Bale adapt late medieval ways of imagining community in order to provoke a shift in allegiance and a reunification of the English nation modelled on patriarchal structures.

The place to begin is in 1518, in Tudor England, where a disguising staged 1 by Henry VIII's revels department signals the unifying potential of the Pagan figure, the Turk. In honor of the "Universal Peace Treaty" signed in London, the disguising relies on the figure of the rancorous, excluded Turk to re-assert the common bonds uniting Europe:

On the rock was an olive tree with the Pope's arms, and a fir tree with the Emperor's arms, and a lily with the arms of the King of France, and a rose tree of roses with the arms of the King of England, and a pomegranate tree with the arms of the King of Spain ... The rider of the Pegasean horse delivered the following explanation: "The rock is the rock of peace. .. And as all these personages rejoice at this peace, as also does the whole world, I planted the trees on the rock of peace." The Turk replied: "Thou speakest not the truth: I, who am of this world, rejoice not at it." The other rejoined, "the whole world rejoices." Thereupon... some 15 armed men appeared on each side and fought a tourney. ${ }^{1}$

The world peace promised by the disguising refers only to the Christian universe depicted by the emblematic trees. The Turk, like Herod in the 
Medieval Cycle plays, does not understand this "world" and does not realize that he is excluded from it by virtue of being a Turk. On the other hand, the blissful assertions of universal peace made by Reaport, Pegasus' rider, cannot be truly enacted until the five distinct trees representing the Royal Houses of Europe and the Pope recognize the common ennemy against whom to mobilize. The tourney which follows the disguising and which, inevitably, finds the European "side" victorious, mimics this mobilization: the Turk's exclusion produces and guarantees the European nations' inclusion into one "side." The European Houses, the disguising suggests, will no longer fight one another, but will be happily united once more in a cosmographic universe defined by the exclusion of the non-European, non-Christian other.

Wishful thinking, at best, of course, as the events of the following few years demonstrated. In 1519, Henry's "minions" were expelled from court in part because of their tendency to identify a bit too closely with France, and by 1522 Henry VIII had allied himself with Charles V against France. ${ }^{2}$ The 1518 disguising itself, by placing the Pope in a position equivalent to the temporal rulers of the great European states, already dislocated the Christian religion from the central position it occupied in the late medieval world: "Universal Peace" of the kind imagined in cosmographic medieval representations, was, due to a variety of factors, becoming impossible in a rapidly changing Europe.

It is the purpose of this essay to trace the impact of this cosmographic disintegration on projections of community in England during the key period of Thomas Cromwell's administration (1532-1540). More specifically, I examine the ways in which old systems of allegiance are interrogated, declared obsolete, and replaced by an emergent nationalism in the texts of two writers closely associated with Cromwell's government: Richard Morison and John Bale. Bale and Morison adapt late medieval ways of imagining community in order to provoke a massive shift in habits of imagining allegiance and identity, and they also draw on contemporary developments - such as, for instance, the proliferation of treason laws and the concern with the nature of the body politic - in an attempt to construct nationhood. ${ }^{3}$ The struggle to represent England is, for Morison as for Bale, a struggle to find a common ground which will allow for a re-unification of the intensely divided body politic. The nation must be able to gather the allegiance of all English subjects, regardless of class, and, ultimately, creed. Despite significant differences in their approaches, both writers respond to this imperative by transferring to the nation the structure of the patriarchal family. The key parental figure becomes not the King, as one would expect, but England itself. In Bale's King Johan (1538) especially, this 
construction of England gives rise to a series of gendered representations that suggest that the "common body" of the nation is defined, not through the exclusion of alien figures like the Turk, but through the rejection of English subjects unwilling to participate in the nation's rigid patriarchal structures.

The shift in ways of imagining community recorded in Bale's and Morison's texts has its roots in a series of significant changes happening in England in the years preceding the period with which I am concerned. The first Tudor reigns coincided with the development of the printing press and with the great voyages of discovery; these in turn facilitated advances in cartography. Conceptions of the geographic world changed radically in Europe as ideas and descriptions circulated more freely. Elizabeth Eisenstein has argued that printing made comparative thinking possible:

[the] heightened awareness of distant regional boundaries was also encouraged by the output of more uniform maps containing more uniform boundaries and place names. Similar developments affected local customs, laws, languages, and costumes. A given book of dress patterns published in Seville in the 1520's made "Spanish" fashions visible through-out the farflung Habsburg Empire. ${ }^{4}$

Ironically, while printing technology allowed for an unprecedented circulation of knowledge, it also served to highlight a new kind of ignorance. The Christian world, homogeneously represented in the Mappae Mundi and the Cycle plays, began to take on much more heterogeneous forms. As new descriptions, maps, and travelogues flooded the European market, as works circulated more freely and Latin gave way to increasingly legitimized vernaculars, the sense of common culture that had united Europe against the pagan world fragmented. Confronted for the first time with such material and cultural differences from the old outlook and the old Europe, the English subject would never again imagine the local community as a microcosm of the larger Christian community.

The Henrician Reformation (1532-1539) provided a framework in which to articulate - perhaps for the first time consciously - this larger cultural shift occurring in the way the English imagined communal life. The government's reliance on printed and dramatic propaganda suggests that the Reformation harnessed pre-existing forms of cultural expression (such as the recently legitimized vernaculars) that carried with them the increasingly popular nationalisms now spreading throughout Europe. The court entertainments that predate the Reformation already showed a tendency towards national stere- 
otyping; long before the Reformation, the figure of the Pagan was making a place for that of the vicious European. ${ }^{5}$ On a more popular level, anti-foreign sentiments ran high and climaxed in the events of Evil May Day (1518), when the London apprentices erupted into a xenophobic riot that involved physical attacks on foreigners as well as the looting of their property. A Doctor Bele, one of the instigators of the riot, justified these measures by arguing that "this lande was geuen too Englishemen, and as byrdes defende their neste, so oughte Englishemen to cherishe and defende them selfes, and to hurt and grieve aliens for the common weale." 6 Significantly, Bele's analogy sought to naturalize the aggressive patriotism he espoused; nevertheless, the leaders of the riots were executed as traitors to Henry VIII.

Because it jeopardized Henry's agreements with foreign princes, nationalistic fervor was, in 1518, both inconvenient and dangerous, particularly among the lower classes. In order for burgeoning English nationalism to assert itself successfully it had to wait for official sanction and the authority of the international community had to be subverted. That came with the anti-papal legislation passed by parliament in the years 1532-1534. Most notably, the Act in Restraint of Appeals (1533) claimed on the basis of "divers sundry old authentic histories and chronicles" that "this realm of England is an empire," not accountable to "any foreign prince or potentates of the world." " This first full-fledged assertion of national sovereignty encouraged the solidification of the various cultural currents which were making nationalistic thinking possible in early modern England. ${ }^{8}$

Recent historians have emphasized the extent to which the English Reformation resulted from the self-interested decisions of career-minded politicians rather than from a wide-based popular movement. Christopher Haigh, for instance, argues that "the English Reformation ... was not a joyous national rejection of outmoded superstition: it was a long drawn-out struggle between reformist minorities and a reluctant majority." Whether or not the "majority" was reluctant, clearly government policies encountered persistent opposition at all levels of society. ${ }^{10}$ The government devised ways of dealing with active opposition: during Thomas Cromwell's tenure 883 English subjects were accused of treason and 308 of these were executed. The nature of the offenses varied widely: some of the executed had participated in the Northern Risings, others had merely expressed unwise opinions too openly. In the year 1538, for instance, the chronicler Edward Hall reports both the execution of Henry Pole, Lord Montague, for alleged collusion with his brother, the Catholic Cardinal Reginald Pole, and that of Friar Forest for denying the 
Supremacy in confession. The friar's case is of particular interest, as it points to what was perhaps the most difficult problem facing the reformers. According to G. R. Elton, Cromwell "had a vision of an England reformed in body and soul [and that is why] he proceeded as he did." "Cromwell's vision necessarily entailed a united England - hence his attempts, for instance, at centralizing the judicial system - but the Reformation was itself intensely divisive. It produced schisms and conflict not only among people, but also, as Friar Forest's case demonstrates, within them as well. Hall describes the case in some detail: the friar "was examined how he could say that the king was not supreme hed of the church, when he him selfe had sworne to the contrary, he answered that he toke his oth with his outward man, but his inward man neuer consented thervnto" (p. 825). Friar Forest's distinction between outward conformity and inward conviction must have been disquieting to his examiners: how many others, wiser than the friar, were successfully able to hide traitorous hearts behind the mask of a loyal subject? And how could an England reformed in body and soul be built from subjects whose "outward man" behaved in opposition to his inner convictions?

Only a conversion would achieve the desired result: the reformers had to perform something like a missionary act on recalcitrant inward men like the Friar. This indeed was tried on the friar himself; but the friar, obstinately refusing the "gentle" attempts of the magistrates to convince him, was "ha[n]ged in chaines by the middle $\&$ armholes al quicke, \& under ye galowes was made a fire \& he so co[n]sumed \& bre[n]t to death." As usual, the execution was extremely theatrical:

there was prepared a great skaffolde, on which sat the nobles of the Realme, and the kynges Maiesties moost honorable counsayle, only to haue graunted pardon to that wretched creature, if any spark of repentaunce woulde haue happened in him: ther was also prepared a Pulpit where a right reuerend father in God and a renouned and famous Clerk the Bishop of Worceter called Hugh Latimer, declared to him his errours and ope[n]ly and manifestly by the scripture of God confuted them, and with many and godly exhortacions moued him to repentau[n]ce, but such was his frowardnes that he neither would here nor speke (pp. 825-826).

Significantly, what was staged with the help of the "great skaffolde" was not only the death of a heretic and traitor, but also his possible conversion by the reformers who, at that time, still had control of Henry VIII's "moost honorable counsayle." It is doubtful, of course, that pardon would have been granted to the friar - how would a true "spark of repentaunce" look in a man who already 
admitted to conforming outwardly despite his convictions? Instead, the performance must have aimed at those who could "here": the audience witnessing the execution. ${ }^{12}$ Latimer's careful enumeration of the friar's "errours" combined with the spectacle of the traitor's tortured body to form a powerful "exhortacion" indeed: the traitorous impulses of Forest's "inward man" were effectively inscribed in his "outward man." At the moment of execution, the two were briefly re-united, a conflation Hall sardonically comments on: "if men might iudge hym by his outward man" forest died "vngodly" (p. 826). What this execution stages, is in fact a reverse conversion: the conforming and deceiving body is molded to the contours of the non-conforming and deceitful soul. In the process, both are "consumed . . . to nothyng." To emphasize the self-consuming nature of the act of treason, the friar was burned with the wood provided by a famous Welsh catholic "Image," the Darvell Gatheren. As Morison, Cromwell's primary propagandist, notes, "traytours can but worke their owne confusion."13

Yet, powerful though such exhortations may have been, they necessarily reached only a limited number of people. And the problem posed by Friar Forest's treacherous duality was, as the Northern Risings demonstrated, widespread. Like the participants in the Pilgrimage of Grace (1536-1537) and the Lincolnshire Rebellion (1536), Forest had failed in accomodating the massive shift of allegiance that was demanded of him: from Pope to monarch, from Rome to London, and from Catholic Europe to England. At the most basic level, this shift of allegiance was a matter of legislation: the Act of Succession (1534), the Act of Supremacy (1534), and the Treason Act (1534) all attempted to insure the transfer of loyalty from Pope to King. While such legislation could enforce conformity, it failed in many cases to instill conviction. Much like Forest, the priest George Rowland, for instance, was investigated by Cromwell in 1536 for suggesting under cover of confessional that an oath, such as the one taken by English subjects to Henry VIII, "loosely made" could be "loosely broken." 14 Both Forest and Rowlands were imprudent enough to share their opinions; others were likely more careful and more successful in hiding similar convictions. Partly as an attempt to convince these others, Cromwell mounted what was to be the first full-fledged governmental propaganda campaign in Europe.

To some extent, the propaganda sponsored by Cromwell served to bring the trials of men like Forest to a broader cross-section of the population: Hall's chronicles and Morison's pamphlets, for instance, contain numerous descriptions of the fate awaiting those who through their own duplicity seek "traitor- 
ously [to] make of one nation two."15 As in Forest's trial, the schism which produced the traitors is seen as a consequence, rather than as a cause, of their duplicity: they wish to project their duality on a nation which is always already one. Legally, of course, treason was strictly defined as a crime against the King. ${ }^{16}$ However, in the process of anatomizing the "unnatural hearts" of traitors and of urging conformity to the Reformation, these pro-government polemicists frequently rely on a definition of treason that comes to compass crimes against the nation as well. Particularly in Morison's work, the listing of failed treasons becomes an emblem of the nation's unity. England itself is born in the confrontation with the traitor:

If England could speak might it not say this? "I am one, why do you make me twain? Ye are all mine; how can any of you, where none ought so to do, seek the destruction of me ... It is a shrewd hand that scratcheth out the eyes, a shrewd foot that for his fault putteth the neck in jeopardy ... I thought if need had been, if mine enemies infested me, to have found help and succor at thy hand; and thou thus traitorously settest upon me..." Thus England might say, and much more, which I will say for her (A Lamentation, pp. 8889).

Morison's reversion to a feminine pronoun for his personified England demonstrates that the entity he refers to is distinct from Henry VIII. Morison speaks for the country, and he is also speaking directly for the Cromwellian government. The strain of patriotic rhetoric that once brought trouble to the Evil May Day rioters had, by 1536, the sanction of official policy.

Cromwell is generally credited with developing the theory of English national sovereignty that led to the anti-papal legislation of the $1530 \mathrm{~s}$, and it is not surprising to find his propagandists echoing his assertions of English insularity. ${ }^{17}$ Morison's tracts go beyond such echoing, however, in developing a secularized version of England that demands allegiance independently of issues of religion and royal rule. In other words, in an attempt to "convert" the populace at large to Cromwell's policies, Morison relies as much on increasingly emotional appeals to nationalism as on the traditional governmental arguments. His tracts laid the groundwork for a nationalistic ideology constructed variously from early modern notions of community, religion, family, honor, and sexuality. This is an ideology that, as we shall see later, finds its fuller expression in a play by another one of Cromwell's protégés, John Bale. ${ }^{18}$ In Bale's King Johan, the vice Sedicyon, disguised as Archbishop Stephen Langton, confesses the character Nobylyte and absolves him of his duty towards King Johan. Nobylyte, although he recognizes that it is "clene against 
[his] nature . . to subdew his kyng," immediately falls victim to the vice's seductions and breaks his oath. ${ }^{19}$ Like George Rowland's and Friar Forest's, Nobylyte's had been but an outward conformity: an oath loosely made and loosely broken. But the play eventually instills in Nobylyte - and the other allegorical characters representative of the various classes of English subjects - something like an inward conviction. They learn to distinguish between what Veritas calls "the suggestyons of the malicyouse clergye" and "a trewthe for [their] owne contrayes sake" (2.2196-2198). By developing the type of nationalism evident in Morison's pamphlets, Bale's play effects the kind of conversion necessary to Cromwell's project of unifying England body and soul.

In the first of the tracts to have survived, Morison re-writes the notion of the Christian community as the body of Christ, arguing that the English commonwealth "is like a body, and so like it that it can be resembled to nothing so convenient as that." Papal control over England threatens to make this body "monstrous" as it grafts a "foreign head" to the native body. By the same token, English internal resistance to governmental assertions of sovereignty threatens to dismember the "body" of the nation. Projecting the division caused by the incomplete Reformation onto Roman Catholicism, Morison notes that "England is little bound unto them that at first divided it so madly." To Morison, the solution to all this divisiveness is obvious: "We must agree in religion, we must serve but one master; one body will have but one head."20 This head is Henry VIII, whom Morison, in this pamphlet as in the ones that follow, consistently lionizes. As the divinely appointed ruler of the country, Henry owes safety to his subjects; they, in turn, owe him obedience. Yet, as Morison notes, there is one area in which every Englishman can equal or even outdo the King: "we might, yea we ought to stryue with his grace, and to desire to overcome hym, in lovynge our countreye." 21

Within Morison's straightforward recitation of the truisms of the Cromwellian government lies a more complex fascination with the "body" of England - a body that takes on a being and a voice of its own independently from Henry, its putative head. A Lamentation indeed moves from arguing through classical and biblical exempla for the necessity for loyalty to the King (120-121) to arguing for the necessity of loyalty to the country (132-133). Noting the courage of "barbarous nations" in defending both King and country, Morison finds himself "ashamed" when he reviews English behavior (120). Part of the problem, he thinks, is regionalism - it is time that Englishmen began defining themselves strictly as Englishmen, and not as Northerners, or 
Southerners, and so on (131-132). But mostly the problem stems from the fact that England is so much richer than other countries, and that its idle and hedonistic inhabitants have abused that richness repeatedly. In England, Morison claims, "the ground almost nourisheth us alone," yet the English have repaid their nurturing land by letting lust and appetite control their attitude towards the country (136-140). This abuse leads the English to sedition and treason, crimes which Morison finds both irreligious and unnatural:

God will not the bonds of nature to be broken, the charity and love that should be between all men, much rather between them that are of one country, one shire, one city, one house, one parentage. . . Nature teacheth brute beasts to love them that gave them life, that nourished them. God saith: honor thy father and mother, love thy neighbor as thyself. Thus he saith, but he is nothing heard where as sedition is. For what sacrifice can the father offer to God and his own country more acceptable than to kill with his own hands his son, now nolenger his son, being a traitor? What act can be more worthy of praise than the son to flee his own father in such a case? He is none of mine, saith Christ, nor worthy to be my servant, that cannot, if just cause require him to do so, forsake his father and mother to do me service. He is none of mine, saith England, that cannot hate his father and mother, that cannot kill them both sooner than once consent to my destruction..$^{22}$

In Morison's formulation, house, city, shire and country are extensions of "parentage": the bonds uniting the English are like the bonds uniting members of a family. Much like Doctor Bele's, this analogy allows Morison to "naturalize" these bonds, a naturalization strengthened by his reminder that the country has "nourished" the English, and that therefore they are bound to love it.

Significantly, Morison calls to God and Nature to justify a nationalism that in turn infringes on both. The "sacrifice" of the father who kills "with his own hands" his son recalls Abraham's intended sacrifice of Isaac, which was read as a type of God's sacrifice of Christ: the treasonous son's death secures the salvation of the country, as Christ's death secures the salvation of human souls. Yet, at the same time, this "sacrifice" also necessarily denies both the law of nature and the law of God: unlike God or Abraham, the patriotic father acts out of "hate" towards his own progeny. Nowhere is Morison's revision of such Christian paradigms clearer than in England's rewriting of Christ's words. To commune with Christ means to "forsake" parentage for his service, but to commune with England entails a willingness to "hate" and "kill" those whom God and nature bid us honor. Like Christ, England requires concrete proof of the bondedness of its subjects, proof that is most easily achieved in the 
"sacrifice" of the traitor, or in the willingness to "die for [the] country" ( $A$ Remedy, 132).

Thus, in Morison's somewhat muddled definition of nationalistic allegiance, nationalistic ties described in terms of kinship take precedence over parental ones, and even over religious ones. "England" in fact subsumes both modes of allegiance: it functions as a nourishing parent and as a Christ-like center of meaning. This becomes clearer in the later pamphlets. In $A$ Lamentation, for instance, Morison asserts that sedition would be horrifying even if one were to "take away the commandments of God, destroy the laws of nature and man." It is "so shameful an act" that it turns the traitor into "a beast" (8586). Unlike Doctor Bele, who did not hesitate likening nationalistic fervor to intuitive animal behavior, Morison insists that the ability to love the nation is precisely that which differentiates humans from animals. To be fully human, for Morison, is to be nationalistic - even, one suspects, to be English.

If treason and sedition are crimes more basic than the laws of nature can account for, nevertheless, traitors are consistently described in Morison's writings as "cruell and unnatural." Traitors are "unnatural" in the sense that they are "unkynd," they "go from the kynde of men, the lose that state and name," they are "tourned" into animals. From treason spring all other "unnatural" vices: murder, rape, sodomy (An Invective, sig. B2v). Like the Pope's the traitor's desire is shamefully carnal. In An Exhortation to Styrre all Englishmen to the Defence of theyr Countrye (1539), Morison's preoccupation with the traitor Reginald Pole leads him into an anecdote that comments on papal pretensions to England. A young bishop hears that a "captain" of the Church is in town, and invites him over for dinner. Courteously, he offers the captain all that is his, including "his body, his harte." The captain takes him at his word, and the next day asks the young bishop to engage in an act of sodomy. Horrified, the young man refuses his "abomynable demaunde," claiming that he would rather "be torne to peces" than commit "so brute and unnatural a synne." But the captain, behaving "like a captain of that church," instructs his henchmen to hold down the bishop and takes him "by force" (sig. C7r-C $\left.8^{\mathrm{r}}\right)$. The anecdote serves, on one level, to illustrate the sexual abuses commonly attributed to the members of the Roman Catholic Church. But within the context of the pamphlet it also serves to underline graphically what Morison calls "the danger [to the] bodye politicke."

In An Exhortation Morison is primarily concerned with foreign invasion: the Pope had excommunicated Henry VIII in 1538, and Reginald Pole, in his role as papal legate very much a "captain" of the Church, was rumored to be 
instigating the Continental princes to an invasion. Although Morison repeatedly asserts that Pole and his henchmen have not half the power to invade as the English have to defend, nonetheless, as Greg Walker notes, behind Morison's rhetoric "lies the fear of a smaller, unprepared nation facing potentially insuperable odds." 23 The Northern Risings demonstrated that the English were open to a seduction by the Pope and Cardinal Pole's "false persuasion." Englishmen had become too lax; they were, Morison suggests through the mediating figure of an "ambassador," in the process of losing the "manhode" of their ancestors (An Exhortation, sig. B3"). Morison, in his descriptions of traitors, consistently denies them any of the traits associated with masculinity in the period: they are all cowardly, carnal, overly talkative, untrustworthy, voracious, shifty. Like sodomy which "stinketh too sore" because it makes men "stand of young wives," treason is unnatural in part because it feminizes and emasculates. ${ }^{24}$ This threat alone should motivate his countrymen to prove that "as long as Englyshe bodies remain in Englande, they shall also fynde Englyshe stomackes, Englyshe handes, Englyshe hartes" ( $A n$ Exhortation, sig. B4 ${ }^{\mathrm{r}}$.

Morison's desire for the integrity of "Englyshe bodies" and English "manhode" translates into a desire to see his countrymen "teare such traytours" as Pole "with theyr teethe": the integrity of the metaphorical "bodye politicke" depends on the actual disintegration of the traitor's body (An Invective, sig. B7 $)$. Since he was educated in Pole's household in Padua, Morison was particularly aware of the seductiveness of that "archtraytour . . . whom god hateth, nature refuseth, all men deteste, yea, and all beastes wolde abhorre."25 His violent harangues against Pole betray a profound revulsion, in part, one suspects, because Pole played such an important role in Morison's own personal history. If, like Cromwell in the Act in Restraints of Appeals, Morison insists on the immemorial antiquity of the English nation, he is also aware of the shortcomings of the recent past. Operative in all of Morison's calls to nationalism is the concept of "shame": shame at unnatural sin, shame at the condition of England, shame at the traitors springing up everywhere, shame at the years of unmanly "bondage [to] the proud tyrant of Rome" endured by the English (An Exhortation, sig. B4 ${ }^{\mathrm{r}}$ ). The focus of all this shame is the figure of England: the nurturing but abused parent, the body threatened by invasion and dismemberment. The "sacrifice" of the traitor ritually enacts and exorcises this communal shame: at the moment of death, the traitor's dismembered body evokes the "monstrous" body politic of the divided nation, a vision which is consumed with the traitor himself. 
Despite his repeated personifications of England, the figure remains abstract and muddled in Morison's work. Its sex is never fully clarified (he refers to England alternatively using neutral or feminine pronouns), and its relations to nature, to God, and to the English themselves are, at best, contradictory. Although England speaks in protest against the unnatural sin of treason, it hardly spreaks for anything else. It rises in pamphlets only in response to the threat of division by the traitor or by foreigners. But in Morison's jumble of metaphors - drawn from religion, from sexuality, from family relations - something like a theory of national allegiance may be glimpsed. Bale's King Johan, written about the same time as Morison's Invective, employs many of the same tools in order to arrive at a more concrete and full articulation of the nation.

King Johan's primary goal may be, as Peter Womack suggests, to impress upon its audience that "the Reformation will be defeated if it is nothing more than a switch in royal policy," but its secondary goals clearly include commentaries on a variety of hot political topics. ${ }^{26}$ For the most part, these commentaries extend - often quite viciously - beyond the official line taken by Cromwell's government. Because of its subject as well as of its performance history, King Johan has been linked more tightly with the Cromwellian government than any of Bale's other plays. ${ }^{27}$ King Johan shares Morison's concerns with the nature of monarchical and papal power, with the crimes of sedition and treason, and with the allegiances of English subjects and the abuses of the clergy. Like Morison, Bale presents England as an immemorial parental entity whose existence necessarily predates its children's and whose claims to their affection are absolute. But whereas Morison recoils from the ingloriousness of the recent past, Bale shoulders the communal shame implicit in Morison's writing and confronts it. Morison's pamphlets attempt to effect conversion in much the same way that Latimer's "many and godly exhortacions" to Friar Forest do: by noting and tracking errors in those already condemned. King Johan's model for conversion, on the other hand, seems to be more akin to the Carmelite friar Bale's own historical conversion to the reformist cause. When he was taunted by his parishioners in Thorndon for having been a friar, Bale retorted "I am neither discontented nor ashamed of it, no more than St. Paul was, when he reported himself sometime to be a pharisee and a persecutor of the Christian sort." ${ }^{28}$ Bale's acknowledgement and acceptance of his own past signified, in this context, the "truth" of his conversion. His very immersion in the now hated religion, like saint Paul's, testifies to the strength of his new faith. Much in the same way, the characters Nobylyte, Cyvyle Order, Clergye, 
and Commynalte are submerged in a degrading bondage to the Pope through much of King Johan; everyone, Bale insists, is complicit in the abuse of England. Acknowledging that complicity is the first step to conversion, and the first step towards establishing a national identity.

King Johan's historical subject matter marks it as a product of its time: ever since the Act in Restraint of Appeals asserted national sovereignty on the basis of "divers sundry old authentic histories and chronicles," historiography had become a volatile political activity. Because it offered to the adept interpreter a series of parallels to Henry VIII's reign, the story of King Johan in particular was something of a cultural touchstone in the period following Henry's break with the Church. So, in 1533, the Vicar of Rye, William Inold, was arrested and examined on Cromwell's order for publicly implying that Henry VIII's incurring of papal displeasure would have the same consequences as King Johan's and that England would pay the same price in the form of bad harvests and epidemic disease. ${ }^{29}$ The vicar's version of John's story directly contradicted the official version - the one followed by Bale - which held that the Pope's interventions in John's realm were acts of "usurped authority." In contesting the officially approved narrative, the Vicar was, in fact, guilty of seditious behavior. His sermon caused disorder in his parish by questioning the King's authority and asserting that of the Pope; consequently, his use of John's story constituted an incitement to disobedience. Although Inold escaped with his life in 1533 , by the next year similar verbal offences could - and did - lead to death under the new Treason Act. ${ }^{30}$

Inold's version of the story of King John was, of course, the traditional one. The incident is instructive because it points to the drastic revisions of culturally significant narratives required by the Reformation. And the drama proved, as Morison himself noted in a treatise advising Henry VIII, an excellent medium for disseminating such revisions. Pamphlets could, after all, reach only the literate portion of the populace, and Morison was interested in involving "all Englyshemen" in his - and Cromwell's - various programs. The polemicist consequently warned Henry VIII of the dangers presented by the old religious plays still being performed around the country, and urged the monarch to replace these with a drama more in keeping with government policies:

Howmoche better is it that those plaies shulde be forbodden and deleted and others dyvysed to set forthe and declare lyvely before the people's eies the abhomynation and wickedness of the bishop of Rome, monkes, ffreers, nonnes, and suche like, and to declare and open to them thobedience that 
your subjects by goddes and mans lawes owe unto your majestie. Into the commen people thynges sooner enter by the eies, then by the eares: remembryng more better that they see then that they heere... ${ }^{31}$

King Johan functions, in many ways, as a response to this call to arms. The hybrid generic nature of the play unites the disparate strands of the medieval drama - the morality, the Cycle play, and the Saint play - into one performance that seeks to "declare lyvely" the "wickedness" of medieval Catholic values..$^{32}$ Bale's preoccupation with the "abhomynation" of Catholicism is evident, for instance, in his revision of the institution of sainthood. King Johan recounts the martyrdom, for his country, of the title character. The King's emphasis on his love for his country and on his faith in Scripture occasions his martyrdom when it causes a confrontation with the Pope (also known in the play as "Usurpyd Powr") and his vices, Sedicyon, Dissymulacyon, and Privat Welth. The conflict results in the King's excommunication and in a papal interdict on the country, but it is only resolved when Dissymulacyon kills Johan in the hope of achieving the status of sainthood:

I do not doubte it but I shall be a saynt;

Prouyde a gyldar, myne Image for to paynt.

I dye for the churche with Thomas of Canterberye

Ye shall fast my vigyll and vpon my daye be merye.

No doubt but I shall do myracles in a whyle

(2.2130-2134).

Like the other vices, Dissymulacyon is identified with the Catholic clergy throughout the play, perhaps wearing clerical clothes made available by the dissolution of the monasteries. Dissymulacyon's dying speech presents the codes that govern Catholic adoration of the saints - the performance of miracles, the martyrdom, the feast days, the images - as ridiculous, naive, and strange. And the vice Sedicyon further underlines this alienness by suggesting that the "crypple, halte, and blynde " as well as "mad men" - outcasts, basically - are the ones who worship saints.

Although he rejects the Catholic faith, the reformed Bale uses its resources in order to further the Protestant cause. King Johan appropriates and redirects the codes by which the medieval Catholic dramas signified. Throughout the play, the saintly Johan stresses the importance of Scripture in providing truth, and the "falshed" (1.274) of Catholic ritual: as Peter Happé notes, "Bale may have rejected the idea of saints as the embodiment of the miraculous ... but he accepted that saints may be used as a means of teaching, of clarifying the nature 
of the Word." ${ }^{33}$ Thus the institution of sainthood is one that Bale adapts to a Protestant and progressive idea of history. He mediates this adaptation through the figure of Veritas who assures us that "no hyghar loue could be/Than a man to peyne hymself for hys own countreye" and places Johan firmly in a canon of such men (2.2260-2267). The context has changed: scriptural authority and nationalistic well-being replace Catholic rituals and institutions. But the martyr remains and the saint's ability to mediate between God and sinner has been replaced by the King's authority as vested in the larger authority of Scripture. Here, indeed, is a play made "to declare and open to them thobedience that your subjects by goddes and mans lawes owe unto your maiestie." 34

But here is also a play, which like Morison's own writings, achieves a number of other purposes. Although King Johan explicitly supports absolute royal authority, it implicitly asserts the primacy of what it calls the "nacyon" (1.1097). Much like Bale himself transferred "the devotion he had formerly felt for the Carmelite order" to "his patria,"35 Bale's play "deleted" medieval religious drama not simply by devising new drama, but by -revising the old forms. Bale consciously dismantles medieval ideas of community as he argues for a transference of loyalty from the Pope to the King. But in order to elicit something like inward conviction from wayward English subjects, the play constructs, out of the remnants of the medieval past, an alternative community. In rewriting the culturally contested narrative of John's reign, King Johan gives expression to a new entity: the "countreye" for whose sake a new truth needs to be established. Morison speaks for England, but Bale brings her on stage: she is visible and concrete, as is the abuse she suffers at the hands of her subjects and of "the bishop of Rome."

Bale's allegorical staging of the English community - variously represented by the monarch, the character Englande, and the characters standing for its hierarchical subdivisions - allows him to juxtapose the nation's unity with its internal division. When the play opens, Englande lodges a complaint with King Johan: she has been injured by "soch as hath enterd" her "by false hypocrysye" (1.30) and reduced her to a miserable state. Although she stands strong against these "dysgysed players" (1.66), one by one Clergye, Nobylyte, Cyvyle Order, and Commynalte succumb to the temptations and threats of the vices. Outwardly faithful to the King, the various members of the English community break their oaths in dizzying succession, becoming "traitors and rebelles" maintained by Sedicyon (1.219). In a play that assigns several characters both allegorical and historical value, Nobylyte, Cyvyle Order, Clergye, and Commynalte remain generalized representations of their class - 
Bale makes no attempt to link them to specific historical traitors, for instance..$^{36}$ Unlike Morison, who could address the immediate past only through virulent and emotional attacks on individual traitors like Pole, Bale confronts the persistence of medieval projections of community, not just as a problem posed by individuals like Pole, Inold, Forest, and Rowland, but as a disease infecting all members of the society.

Like the medieval salvation histories, King Johan is governed by the metaphor of the social body, and concerned with its wholeness. Bale follows Morison in shifting the nature of that body from that of Christian world to that of "Englande." However, the parts of the body - represented by Nobylyte, Clergye, Cyvyle Order, and Commynalte - have, when the play opens, not yet accepted that shift. The play thus recounts their necessary transference of "trew alegyauns" (1.5) from the Christian world to England. King Johan models this allegiance by "havyng to Englande all his loue and remorse" (1.578) - a sharp contrast to the mixed loyalties of his subjects.

Bale's play speaks clearly on the nature of the shift of allegiance demanded of English subjects, arguing for a replacement of the medieval dialectic between the local and the cosmographic with a dialectic between the individual and the nation. King Johan invokes medieval macrocosmic and cosmographic representations only to dismiss them in favor of the geographically and politically bounded entity known as England. Bale revises the homogeneous geography of the Christian world by suggesting that it is bound together not by Christ but by "iniquite" (1.292); "throw-out all Christendom" (1.273) vices like Sedicyon and Dissymulacyon hide under the cloak of Christianity in order to "dystroye mennys sowlles with damnable superticyon / And decaye all realmys by meyntenaunce of sedycion" (1.496-497). The link between the destruction of English "mennys sowlles" and the "decaye" of England itself is one Bale makes repeatedly: national integrity depends on the health of individual souls, their willingness to acknowledge themselves "chylderne" to England (1.68). Notably, the vices who encourage Clergye, Commynalte, Nobylyte, and Cyvyle Order to commit treason by denying their status as Englande's progeny are specifically extra-national. When King Johan, Morison-like, marvels that Sedycyon is "to Englond to vnnaturall; / Being her own chyld" and accuses Sedycyon of being "worse than a best brutall" (1.177-178), the vice reacts strongly. He refutes kinship to England, claiming to be "sumtyme in Englond," but born neither there, nor "in Spayne, nor in Fraunce" (1.181-182). Like the other vices, Sedicyon acts as a figure for the unity of the Christian world. He resides "bothe in hevyn and erthe and also 
in purgatory" (1.209); he has the same sense of cosmographic power as the Pagan tyrants of the Cycle plays. Sedicyon is continually

In Sycell, in Naples, in Venys and Ytalye,

In Pole, in Sprvse, and Beine, in Denmarke and Lumbardye,

In Aragon, in Spayne, in Fraunce and in Germanye,

In Ynglond, in Scotlond, and in other regyons elles.

Here, in contrast to the Cycle plays, the greater supremacy of Christ's body never challenges the vice's claims to unifying the geographical Christian world. Instead, Bale's play imagines the way to Christ as a separation and an assertion of difference from Catholic universality. This difference is established in part through the appearance of the character Englande, who represents the unity and coherence implied in King Johan's construction of the English geographical space as a "nacyon," while underlining the threat posed to that community by international claims.

In Bale's play, Englande is a woman. King Johan, Commonalty, Clergye, Cyvyle Order, and Nobylyte are all men. Together, they comprise what the play seems to understand by the word "nacyon." King Johan imagines the nation's space - its body - as limited, passive, ideal, and feminine. As a woman, Englande is particularly vulnerable to the mysogynistic degradations of Sedicyon, who dismisses her complaints as feminine "bablyng"(1.156), and derides Johan for being "a man so full of mercye, / Namely to women [th]at wepe with a hevy harte / Whan they in [th] churche hath lett but a lytyll farte" (1.164-166). Sedicyon's virulent constructions of Englande effectively reduce her to the early modern stereotype of a wanton woman: she overflows from all orifices and must at all costs be silenced. Incapable of defending her own honor against Sedicyon's attacks, Englande needs men to "further [her] cavse and to mayntayne [her] ryght" (1.138). Speaking to his assembled subjects, King Johan defines the proper patriarchal attitude that will safeguard the country:

For the love of God, loke to the state of Englond!

Leate non enemy holde her in myserable bond.

Se yow defend her as yt becummyth nobilite,

Se yow instructe her acordyng to yowr degre,

[...]

Thus shall she florysh in honor and grett plente.

England's sovereignty thus depends on the men who inhabit and "instrutte" 
her, who should safeguard her from invasion, police her boundaries, defend her honor. Alternatively, imagined as children of Englande or as her husband, the characters Nobylyte, Clergye, Cyvyle Order, Commynalte, and King Johan should be - and are, by the end of the play — united by their common relationship to the feminized space of the nation, despite their differences in "degre."

Bale's transference of the metaphorical marriage between Christ and the Church to an equally metaphorical marriage between Englande and King Johan plays a key role in this unification. Married originally to God, Englande finds her husband exiled through the machinations of the Pope. The Church forces her to pay "[th]e spoyle / Of her londes, her goodes, and of her pore chylderes toyle" (1.417-418) and her children have misused her so that she looks notably "wan and pale" (1.57). Over the course of the play, Englande's status as God's widow slowly gives way to an intimate tie with Johan himself. She describes their relationship in terms that echo a wedding ceremony: she was "gevyn hym of the Lord Omnypotente" and will not leave him until "deth shall us departe" $(1.1615,1622)$. She offers King Johan her son, and when the King dies, she performs a "wydowes office" (2.2185) for him. Johan himself returns her devotion, dying for her sake. Bale presents the relationship between Englande and Johan as pure and loving - failing only when the children for which they care are "bastardes . . . unnatural" (1.69), willing to reject their "natural" mother in favor of "the mother of whordom," the Roman Catholic Church (2.494).

Bale's representational strategy thus gives the nation an intimate, familial structure. The female country, the male monarch, and the male subjects are united by the bonds of kinship. Like Morison, Bale seeks to make of England a center of meaning that subsumes religious allegiance. But in adapting religious motifs to nationalistic purposes, Bale finds a model far more powerful and inclusive than Morison's: in King Johan, Englande functions at times like the Catholic Virgin Mother. Consequently, whereas Morison's attempts to link both family and religion to the nation ended in contradiction, Bale successfully yokes the two. His England is at once source of comfort and object of adoration, at once family and religion. Even while she gradually assumes the position of Johan's wife, for instance, Englande's attitude towards Johan remains maternal, and in his death scene, their relationship is dramatically likened to that of the Virgin Mary and Christ. Like Christ, Johan dies from Dissymulacyon's "false Judas kysse," generously forgiving those who have wronged him (1.2144). Englande vows to keep his "body for a memoryall" (2.2183), and, picking him up as he dies, exclaims 
Alas, swete maistre, ye waye so heauy as leade.

Oh horryble case, that euer so noble a kynge

Shoulde thus be destroyed and lost for ryghteouse doynge

By a cruell sort of disguysed bloud souppers -

Vnmercyfull murtherers, all dronke in [th]e bloude of marters!

(2.2186-2190)

The image is familiar: Englande and her martyred king form a sort of nationalistic pietà. Together, they collect about them all the virtue and righteousness in the play, as well as all the warmth and love. Johan's martyrdom for "swete Englande" (2.2178) is the best way to emulate Christ.

Bale's feminization of England also allows him to present questions of invasion, of boundaries, and of possession within a familiar context of patriarchal values. England provides and nurtures like a mother, but she is also a maiden, and therefore her "every border" must be watched to prevent alien entry (2.1258). Significantly, the vice Privat Welth imagines the forces threatening England under the aegis of the Pope's transnational authority in nationalistic terms:

We have vn [th]e northe, Alexander [th]e kynge of Scottes,

With an armye of men [th] at for their townnes cast lottes;

On the sowthe syde we haue [th]e french kyng with his powr,

Which wyll sle and burne tyll he cum to Londen towr;

In [th]e west partes we haue kyng Alphonse with the Spanyardes With sheppes full of gonepowder, now cummyng hether towardes, And on [th]e est syde we haue Esterlynges, Danes and Norwayes With soch powr landynge as can be resystyd nowayes.

(2.1632-1639)

The specificity of this description underlines England's status as a bounded entity surrounded by invasive cultures, ready to separate "townnes" that elsewhere in the play are united firmly under King Johan's care. ${ }^{37}$

Because England's space is imagined as feminine, such invasive plans are frequently characterized in sexual terms. Sedicyon, for example, continually refers to Englande as a whore and a harlot; these references betray his own desires to make her one. When his plans finally do succeed, he immediately puts his desires into action; he tells her "holde your tunge, ye whore, or by [th] messe, ye shall repent! / Downe on your mary bones, and make nomore ado" (2.1714-1715). This formulation is overtly sexual, its violence undisguised. The unification of the Catholic Church makes nations subservient, and King Johan figures this subservience most frequently as sexual degrading. Among 
the many "great displeasures of warre" discussed by Johan, the "defylynge of maydes" takes on a particularly ominous quality given the representation of England in the play (1.1705-1709). Johan capitulates to the pressures of the Pope and hands over the crown in part to prevent such "defylynge." When England protests the King's actions, he asks her to "shewe [her] selfe a mother" (2.1717) towards the people he seeks to protect from war. But by handing over England to the Pope, the King eradicates her capacity to show herself a good mother and protect her children. Sedicyon's possession of England, that "most plesaunt grounde / In all the rounde worlde" allows him and the Pope to act on their hedonistic fantasies (2. 1684-1686). Englande herself describes her bondage to the "holye father" in terms of dishonor and enforced prostitution:

Alacke for pyte that euer ye grantyd this.
For me, pore Ynglond, ye haue done sore amys;
Of a fre woman ye haue now mad a bonde mayd.
Yowr selfe and heyres ye haue for euer decayd.
Alas, I had rether be vnderneth the Turke
Than vnder the wynges of soch a thefe to lurke.

(2.1765-1770)

As Englande implies, the Holy Church thus confounds the realm by raping her, by forcing the country, "a bonde mayd," to produce "bastardes" who threaten the legitimate inheritance.

Englande's revulsion at being under the yoke of the Christian world is such that she prefers to be "underneth the Turke." Thus, the emblematic heathen of the medieval world, a figure still potent enough to produce European unification in the 1518 disguising, cedes his place to others in a play which seeks to assert the alienness of traditional European modes of allegiance. Here, as elsewhere, King Johan is articulate about the nature of this shift. Bale evokes the figure of the Turk not to differentiate him from Englande and Johan but to make the identification. Bale's play imagines the Turk's resistance to the Catholic Church as exemplary rather than threatening. In Dissymulacyon's description of Usurpyd Powr, for instance, the vice explicitly links the pope's attempts to subdue Johan with the "christen vyolens" practised against the Turks (1.1005-1015). Later, Sedicyon urges Clergye to show Johan "no more faver than a Turcke" (2.1242). Such references inevitably establish a parallel between the play's main character and the heathen of the medieval world; as a result, Bale radically revises the figure of the Turk by enlisting the audience's sympathy with the pagan's suffering at the hands of "christen vyolens." Englande herself clarifies the fact that the exclusion of the 
Turk no longer functions as a way of uniting the community: "There is no promyse for voluntarye wurkes, / No more than there is for sacrifyce of the Turkes" (2.2154-2155). Instead, the unifying sacrifice aims to do away with those who threaten Englande: the foreign vices who represent the treasonous impulses of her own subjects. "The Turkes," Veritas asserts forcefully, "are a thousande tymes better" than England's unnatural children (2.2305). Bale's play finally insists on the allienness not of the heathen, or even of the Catholic European, but of the unnatural English subject.

Through his representation of England as a mother, Bale naturalizes the national community even as he constructs it. And by figuring the threat to the English nation in terms of a possible rape, Bale strategically evokes the familiar patriarchal concern with female chastity and patrilinear inheritance, "successyon lyneall" (1.11).$^{38}$ One of the clearest signs of Nobylyte's seduction by the Catholic vices lies in the fact that he has "gevyn londes full fayere / And [has] dysheryted many a lavfull ayere" (2.1132-1133). The crime against the chaste "realme" committed by the supra-national Christian community is thus, as Nobylyte emphasizes towards the end of the play, also a crime against the "manhode" of its inhabitants (2.2654). Although King Johan himself carefully models the nurturing, patriarchal relationship that represents "trew alegyauns" to and participation in the nation, his subjects remain seduced by the antics of the foreign vices, a seduction that makes them, as the play repeatedly insists, at once bastards and traitors.

Indeed, according to a pseudo-etymology of the time, the word sedition derived from the Latin verb seducere, to seduce ${ }^{39}$ In this context, the vice Sedicyon's characterization as a "lewde person" intent on promoting "bycherye" becomes particularly significant: his sexual designs on England activate this level of meaning (1.44-45). Morison, as we saw earlier, already toyed with the latent sense of "sedition" by emphasizing the seductive powers of the Pope's and Pole's "false persuasion," and by associating treason with sodomy, an act the pamphleteer clearly considered repulsive. But Bale makes a link between aberrant sexuality and treason explicit. When Imperyall Majestye orders Sedicyon drawn, hanged and quartered for treason, such a punishment is appropriate not only because of Sedicyon's large-scale attack on English subjects' loyalties and his scurrilous remarks about King Johan. Sedicyon is also guilty, under the laws of the time, of violating the King's consort Englande - and thus threatening legitimate succession. This particular aspect of the treason law is, given the notoriety of the Bolleyn trials (1536), a pertinent context for the play. 
Because of the marriage between England and King Johan, Bale's treatment of treason transforms what was originally a crime against the King into a crime against the country. Moreover, since the character Sedicyon is an externalization of the feelings and allegiances harbored by England's children - a point made clear, for instance, in Imperyall Majestye's assertion, at the end of the vice's "trial," that he sees "by this wretche" that "there hath bene muche faulte" in English subjects (2.2593-2594) - the traitor transgresses against a natural world order. ${ }^{40}$ In King Johan, treason, imagined as a violation of Mother England, becomes a crime that gathers to it all the forces of an incest taboo. The play equates "the love of God" with a care for "the state of Englande," and it accuses the English subject unwilling to acknowledge England's primacy of being an "unnatural" bastard (1.69). The Pope's alias, Usurpyd Powr, suggests that the reign of the universal Catholic community usurps a "natural" world order based on nationality, so that England, over the course of the play, reclaims her "ryghtfull herytage" (1.169). Despite Sedicyon's protests that she is a "folysh woman," a "queane," and a "callet" who mocks his "blessed storyes" (2.1907), England in the end secures the allegiance of her children. They put off their "dysgysed coates" (2.2573) to don the mantles of true subjects.

Nobylyte, Clergye, Commynalte, and Cyvyle Order are converted by the figure of Veritas, who underlines once again the transgressive nature of their allegiance to the trans-national Catholic world:

Plato thought alwayes that no hyghar loue could be Than a man to peyne hymself for hys own countreye.

Dauid for their sake the proude Phelistyan slewe,

Aioth mad Eglon hys wyckednesse to rewe,

Esdras from Persye for hys owne contreys sake

Came to hierusalem, their stronge holdes vp to make;

But yow, lyke wretches, cast ouer both contreye and kynge.

All manhode shameth to see your vnnatural doynge.

(2.2259-2267)

Shame, in Veritas's sermon, becomes the instrument for instilling an inward conviction. Faced with their own "vnnatural doynge," the penitent children of England quickly acknowledge that they are "ashamed" and have "done sore amys" (2.2603). Their conversion is celebrated and finalized when they join together with Imperyall Majestye to condemn Sedicyon to his traitor's fate. According to the laws of the time, traitors were drawn to execution, hanged, cut down alive, emasculated, disembowelled, beheaded, and finally quartered. The quartered pieces were then frequently displayed in the various parts of the 
country that the traitors had endangered. ${ }^{41}$ Over the prospect of this dismembered body, the divided nation reunites.

Significantly, these moments of conversion and reunion coincide with the disappearance, from the stage, of the character Englande. She becomes, instead, internalized: a common point of reference to the remaining characters who end the play by praying for "the confort of this nacyon" (2.2689). The transfer of allegiance has been successfully negotiated, the social body has recovered its harmony, and something like an inward conviction about their duties has been instilled in its members. This inward conviction, born in a moment of communal shame, and mediated through the quasi-religious maternal body of England, could also be termed a sense of national identity. And, as we have seen, this national identity is already gendered: it offers as the focus and fulfillment of masculine desire and comradery an England who is at once ideal mother and ideal lover, and who, in order to breed properly, must paradoxically be kept chaste.

Bale's representation of England provides a solution to one of the major obstacles facing emergent nationalism in England. Benedict Anderson argues that, for nationalists, "nations . . . always loom out of an immemorial past." 42 King Johan originated partly in an attempt to create such a past, to substantiate Cromwell's claim that "divers sundry old authentic histories and chronicles" prove England to be sovereign - a claim that already betrays, in its layering of authorizing adjectives, a certain nervousness about its truth-content. Such "histories and chronicles" were in fact harder to come by than the Act in Restraint of Appeals suggests. The "many excellent [English] writers Bale cites in support of his version of John's story do not in fact differ much in their opinion of the King from the Italian Polydorus who "reporteth hym very yll / At the suggestyons of the malicyouse clergye" (2.2195-2196). The "written storyes" of John's reign were, from the ideological point of view taken by Bale's play, little more than "shamelesse lyes" (2.2289-2290).

Ultimately, historiography proved unreliable for Bale's purposes: David Scott Kastan notes that in King Johan

History needs Scripture and Scripture history if either is to serve to authorize the English nation, but their reciprocal need reveals them both to require grounding rather than to provide it, reveals their authorizations, that is, to be contingent and rhetorical rather than logical and absolute. ${ }^{43}$

Both Bale and Morison bridge this impasse by producing a different form of authority altogether - an authority based on what Anderson terms the "profound emotional legitimacy" of nationalism. ${ }^{44}$ Although these writers insist that a true 
subject must be willing to die for the sake of England, neither finally achieves a "logical" argument to that effect. Instead, Bale and Morison reframe various concepts and vocabularies guaranteed to strike a chord with their audiences concepts like shame, parentage, patriarchal order - in terms of England, and thus provoke a profound emotional reaction that serves to produce the nation.

Bale's construction of England proves particularly effective by providing a fantasy of maternal origin which presents the nation, at least metaphorically, as immemorial. As the object of nostalgic desire, Mother England delivers "emotional legitimacy" and elicits "natural" allegiance. Furthermore, the figure of England allows for a rigorous definition of appropriate nationalistic behavior - modeled on chivalric honor, filial devotion and paternalistic concern. By linking emergent nationalism to the structures of patriarchy, Bale effectively strengthens both: patriarchal control ensures national sovereignty, nationalism in turn works to justify patriarchal ideology. Bale's construction of England serves to brand any action that deviates from this strictly circumscribed set of relations as unnatural, illegitimate, and incestuous. The embarrassing servitude of the English to the Pope, the historiographic records that trace this servitude, and the English subjects willing to continue under such bondage all derive from perverse misreadings of the family structure provided by the nation.

Yet, in Morison's and Bale's writings, the ones who are sacrificed for the nation are precisely these unnatural subjects: the communal body unites most forcefully at the moment it amputates its diseased members. Whereas the Catholic community of the medieval world found its unity in the rejection and persecution of heathens, the emergent national community thus fashions itself in opposition to the enemy within. This confrontation is most visible in the numerous and spectacular treason trials of the sixteenth century. ${ }^{45}$ But, as Bale and Morison demonstrate, the enemy within did not in fact have to be embodied to be an effective foil to nationalism. He or she could be represented in writing and on stage. And although Bale's gendered construction of England frequently appears strident, she is nevertheless the cultural ancestor of Shakespeare's England, whose "gentle bosom" is, in the history plays, regularly violated by her unkind "sons and children." ${ }^{6}$ Womack argues that "given ... the undiminished strength of nationalism as a political motive across Europe and the world," the study of its emergence in early modern England is not just relevant to a handful of Renaissance scholars. ${ }^{47}$ It is particularly important that we examine the symbiotic relationship between nationalism and patriarchy during this period. The consequences (to English subjects and English enemies alike) of the gendered structures I have been tracing are too many to explore 
here, and one example will have to suffice. Implicit in Bale's construction of the invasion of England as a rape is the idea that rape can serve to destroy another nation's sovereignty. The final image I wish to raise is, considering the recent use of rape as a nationalistic weapon in the former Yugoslavia, a particularly timely one. It is the image of the greatest national hero in the English history plays, warlike Harry himself, in front of the gates of Harfleur, threatening the "hot and forcing violation" of the "pure maidens" of France. ${ }^{48}$

\section{University of North Texas}

\section{Notes}

1. This anonymous description is printed in The Calendar of State Papers (Venetian), ed. Rawdon Brown (London: Longmans, Green, Reader \& Dyer, 1867), 2.1088. For a shorter description which identifies the figure on Pegasus as "Reaport," see Edward Hall, The Union of the Two Noble and Illustre Famelies of Lancaster and Yorke (London: J. Johnson, 1809), p. 595. The disguising is also discussed by Sydney Anglo, Spectacle, Pageantry, and Early Tudor Policy (Oxford: Clarendon Press, 1969), pp. 131-132.

2. On these and related events, see David Starkey, The Reign of Henry VIII (London: Collins and Brown, 1991), p. 77.

3. Leonard Barkan notes that Renaissance England "represents in a way the heyday of the anthropomorphic image of the commonwealth," consolidating classical and medieval habits of imagining the community as a body "with new imaginative force and with new applications to the political world around them," Nature's Work of Art: The Human Body as Image of the World (New Haven: Yale University Press, 1975), p. 75.

4. The Printing Revolution in Early Modern Europe (Cambridge: Cambridge University Press, 1983), p. 55.

5. Note, for instance, the frenchified vices in John Skelton's Magnificence (1515-1516).

6. The events leading to the Evil May Day riots are recorded in Hall, The Union, 586-591.

7. J. R. Tanner, ed. Tudor Constitutional Documents (Cambridge: Cambridge University Press, 1922), p. 41.

8. For a fuller discussion of the developments which led to the birth of the English nation-state, see for instance Alan G. R. Smith, The Emergence of a Nation State: The Commonealth of England, 1529-1660 (New York: Longmans, 1984), 3-47.

9. "Conclusion," in Christopher Haigh, ed. The English Reformation Revised (Cambridge: Cambridge University Press, 1987), p. 209.

10. G. R. Elton's Policy and Police: The Enforcement of the Reformation in the Age of Thomas Cromwell (Cambridge: Cambridge University Press, 1972) marshalls an impressive amount of evidence in support of this view. The statistics for treason cases which follow are Elton's, p. 393. 
11. Elton, Policy and Police, p. 424.

12. The idea that executions were staged in order to impress certain concepts on the attending public is familiar to readers of Michel Foucault's Discipline and Punish: The Birth of the Prison (New York: Random House, 1979), 3-72. The didactic purpose of the executions of traitors was widely acknowledged in the sixteenth century: for instance, Anthony Munday, in A Discoverie of E. Campion and his Confederates, their most horrible and traitorous practices ... Whereto is added the execution of Edmund Campion. . . (London: Edwarde White, 1582) notes that his "discourse" will allow the reader "to be warned . . to remaine euer a loyall and faithfull subiect" (sig. B1 ${ }^{\mathrm{r}}$ ).

13. Richard Morison, An Invective Ayenste the great and Detestable Vice, Treason, wherein the Secrete Practices, and Traitorous Workinges of Theym, that suffrid of late, are disclosed (Amsterdam: Theatrvm Orbis Terrarvm, 1972), sig. a4v

14. For Rowland's and similar cases see Elton, Policy and Police, 24-33.

15. Richard Morison, A Lamentation in Which is Showed what Ruin and Destruction Cometh of Seditious Rebellion [1536], in David Sandler Berkowitz, Humanist Scholarship and Public Order: Two Tracts Against the Pilgrimage of Grace by Sir Richard Morison (Washington: Folger Shakespeare Library, 1984), p. 88.

16. The most complete discussion of the development of the English treason laws is $\mathbf{J}$. G. Bellamy's The Law of Treason in England in the Middle Ages (Cambridge: Cambridge University Press, 1970). For Henrician revisions and additions to these laws, see also Elton, Policy and Police, 264-292.

17. G. R. Elton traces Cromwell's development of this theory in Reform and Reformation: England 1509-1558 (London: Edward Arnold, 1977), 145-156.

18. Although the extent of the patronage received by Bale from Cromwell is still a matter of discussion, Cromwell saved Bale on several occasions for legal troubles. For a description of these events, as well as other details of Bale's tempestuous career, and a bibliography of his works, see Leslie P. Fairfield, John Bale: Mythmaker for the English Reformation (Lafayette: Purdue University Press, 1976).. Cromwell's accounts record two payments to Bale for plays, on September 8, 1538 and on January 31, 1539, see W. R. Streitberger, Court Revels 1485-1559 (Toronto: University of Toronto Press, 1994), pp. 279-280. As Streitberger notes, the latter payment may have been for King Johan, which was performed at Archbishop Cranmer's house during the 1538-1539 Christmas season (see also note 33 below).

19. King Johan, ed. Barry B. Adams (San Marino, CA: Huntington Library, 1969), 2.11761177. All references to King Johan are to this edition.

20. A Remedy for Sedition Wherein are Contained Many Things concerning the True and Loyal Obeisance That Commons Owe unto Their Prince and Sovereign Lord the King [1536]. In Humanist Order and Public Scholarship, pp. 118-129. This pamphlet, like A Lamentation, was written in the wake of the Northern Risings and is consequently preoccupied by the types of sedition evinced by the Northern rebels.

21. An Exhortation, sig. D4r. 
22. A Remedy, p. 122. Although technically sedition and treason are different crimes, Morison, like Bale, uses the terms interchangeably.

23. Plays of Persuasion: Drama and Politics at the Court of Henry VIII(Cambridge: Cambridge University Press, 1991), p. 198.

24. A Lamentation, p. 94. For Morison's feminization of traitors, see especially his descriptions of Pole and his family in An Invective, sig. B3 ${ }^{\mathrm{r}}-\mathrm{F}^{\mathrm{r}}$.

25. An Invective, sig. B3r. For Morison's education in Pole's household, see Elton, Reform and Reformation, p. 158.

26. "Imagining Communities: The Theatre and the English Nation in the Sixteenth Century," in David Ayers, ed. Culture and History, 1350-1600: Essays on English Communities, Identities, and Writing (New York: Harvester Wheatsheaf, 1992), p. 119. Womack is intent on locating the emergence of English nationalism in Elizabethan times, and characterizes King Johan as an aberrant, if interesting, Henrician forerunner. Although the play stages "an attack on the Catholic Church ... in the name of the national community" (p. 117), Womack claims it finally fails to invite the audience "to recognize itself as a community" (p. 119). Many critics of the play differ with Womack in stressing the play's political commitment over its religious one. Of course, the two are, in this period, practically inseparable. Nevertheless, David Scott Kastan argues forcefully that the emphasis is "more upon politics than theology," and that King Johan is in fact primarily concerned with writing the nation, “"Holy Wordes' and 'Slypper Wit': John Bale's King Johan and the Poetics of Propaganda," in Peter Herman, ed. Rethinking the Henrician Era: Essays on Early Tudor Texts and Contexts (Chicago: University of Illinois Press, 1994), p. 269.

27. The details of King Johan's connection to the government have been documented widely elsewhere. See, for instance, Walker, who reviews the play's connection to Cromwell and links specific moments in the play to events in Henry VIII's reign; Paul White, Theatre and Reformation: Protestantism, Patronage, and Playing in Tudor England (Cambridge: Cambridge University Press, 1993) who argues that Bale wrote in support of Cromwellian reform policies (21-41); and Kastan, “'Holy Wordes' and Slypper Wit"” who argues that King Johan was “designed precisely” to respond to Morison's advice about plays (p. 269). Attempts to link Bale's other plays to specific Cromwellian agendas are less frequent, but see, for instance, Seymour Baker House, "Cromwell's Message to the Regulars: The Biblical Trilogy of John Bale, 1537," Renaissance and Reformation, 15, 2 (1991), 123-138, who argues that Bale's trilogy on John the Baptist was used by Cromwell to address reluctant subjects - in particular the Cluniac monks at Thetford.

28. John Bale, quoted in Fairfield, p. 47.

29. For Inold's case, see Elton, Policy and Police, p. 86.

30. For a detailed analysis of the Treason Act of 1534, see Elton, Policy and Police, 264-292.

31. Quoted in an extract from this treatise, entitled "A Discourse Touching the Reformation of the Lawes of England," printed in Sydney Anglo, "An Early Tudor Programme for Plays and Other Demonstrations Against the Pope," Journal of the Warburg and Courtauld Institutes, 20 (1957), 177-179. 
32. King Johan's connection to the morality genre has long been acknowledged: see, for instance, Adams, "Introduction," 58-65. I am indebted for the ensuing discussion of Bale's treatment of the institution of sainthood to Peter Happé, "The Protestant Adaptation of the Saint Play," in Clifford Davidson, ed. The Saint Play in Medieval Europe (Kalamazoo: Western Michigan University Press, 1986), 205-226. For King Johan's connection to the Cycles, see below.

33. Happé, “The Protestant Adaptation,” p. 214.

34. Streitberger notes that "there is clear evidence that Cromwell did patronize and otherwise lend his support to propagandist playwrights," including Bale, Court Revels, p. 146, and the recorded performance of King Johan at Archbishop Cranmer's House suggests that Cromwell's administration made use of the play for propagandistic purposes such as the ones outlined by Morison. Where Morison's work reached only an elite, plays like Bale's could technically be performed by anyone - even the "commen people" - and White has suggested that Bale's troupe "toured extensively during the late 1530's," Theatre and Reformation, p. 41. Unfortunately, White's attractive hypothesis is based in part on the (relatively commonplace) identification of Bale's troupe with the Lord Privy Seal's Men, an identification which was recently questioned due to a lack of evidence by Streitberger, Court Revels, p. 147.

35. Fairfield, John Bale, p. 50. Fairfield gives an extensive account of Bale's transference of loyalty from the Carmelite Order to England, 50-119. As Fairfield notes, Bale's commitment to his country was real and influenced all of his post-conversion writings. The most impressive testament to Bale's patriotism is probably his catalogue of English writers, the Index Brittaniae Scriptorum, ed. R.L. Poole and Mary Bateson (Oxford: Oxford University Press, 1902). Andrew Hadfield provides the best critical account of Bale's other contributions to nationalistic literature: Literature, Politics and National Identity: Reformation to Renaissance (Cambridge: Cambridge University Press, 1994), 51-80.

36. Sedicyon becomes for part of the play Stephen Langton, Archbishop of Canterbury; Dissymulacyon doubles as the monk reputed to have killed Johan, and so on.

37. For the ways in which the possibility of foreign invasion in the play reflects the actual fears of Henry VIII's government, see Walker, Plays of Persuasion, pp. 196-200.

38. Michael Weisser notes that since the stability of the social order was "based upon marriage and inheritance," early modern society was "more directly threatened by rape than by murder": Crime and Punishment in Early Modern Europe (Atlantic Highlands, NJ: Humanities Press, 1979), p. 40.

39. The Oxford English Dictionary notes that "The ME. spelling seducioun, seduccione are due pseudoetymological association with L. seducere SEDUCE v."

40. Imperyall Majestye's duplicitous treatment of Sedicyon during the trial may have been modeled on Henry VIII's treatment of Robert Aske, one of the leaders of the Northern Rebellions. See Jesse W. Harris, John Bale: A Study in the Minor Literature of the Reformation (Freeport, NY: Books for Libraries Press, 1970), pp. 95-96.

41. Anthony Munday describes the legal sentence passed on traitors in detail: "That they should depart to the places from whence they came, and from thence to be drawne on hurdles to the 
place of execution, where they should be hanged tyll they were halfe dead, then to be cutte downe, their privie members to be cutte off, and their entrayles taken foorth, and to be burned in the fire before their eyes: then theyr heades to be cut off, their bodies parted into foure quarters, to be disposed at her Maiesties pleasure, and the Lord God to receiue theyr [s] loules to his mercie." A Discoverie, sig. F4v-F5'. Members of the nobility who committed treason were spared most of this punishment and were simply beheaded; common women accused of treason were burned since the display of their bodies was deemed immodest. See John Laurence, A History of Capital Punishment (London: Kennikat Press, 1971), p. 6. The habit of emasculating traitors is particularly interesting in the context of my argument, since emasculation was the punishment reserved for rapists in the Middle Ages: see George Ives, A History of Penal Methods (Montclair, NJ: Patterson Smith, 1970), p. 12. Also, this particular mutilation can be read as the inscription on the body of the feminine aspects of treason discussed above.

42. Benedict Anderson, Imagined Communities: Reflections on the Origins and Spread of Nationalism (New York: Verso, 1983), p. 19.

43. Kastan, “'Holy Wordes' and 'Slypper Wit”, pp. 278-279.

44. Anderson, Imagined Communities, p. 14.

45. Lacey Baldwin Smith notes that treason came to be an obsessive concern of Tudor society; in fact he terms this crime the "signature of the age," Treason in Tudor England: Politics and Paranoia (London: Jonathan Cape, 1986), p. 30.

46. William Shakespeare, King John, in The Riverside Shakespeare, ed. G. Blakemore Evans (Boston: Houghton Mifflin, 1974), pp. 769-799.

47. Womack, "Imagining Communities," p. 96.

48. William Shakespeare, Henry V, in The Riverside Shakespeare, pp. 935-974. 